\title{
A Poly(oxyethylene)-Supported Cys-Pro-Leu-Cys/Fe(II) Complex as a Rubredoxin Model: Protection of the Fe-Cys Coordination from Hydrolysis in Aqueous Solution
}

\author{
Norikazu Ueyama, Michio NaKata, and Akira NaKamura* \\ Department of Macromolecular Science, Faculty of Science, \\ Osaka University, Toyonaka, Osaka 560, Japan
}

(Received September 17, 1984)

\begin{abstract}
Hg}(\mathrm{II})$ and $\mathrm{Fe}(\mathrm{II})$ complexes of PEG-CO-Cys-Pro-Leu-Cys-OMe (PEG= poly(oxyethylene)) each having an invariant sequence of rubredoxin were synthesized. The complexes were characterized by ${ }^{13} \mathrm{C}$ NMR and $\mathrm{CD}$ spectral methods. In aqueous solution, the $\mathrm{Fe}(\mathrm{II})$ complex is considerably resistant to hydrolysis compared to the $\mathrm{Fe}$ (II) complex of PEG-COCys-OMe because of protection of the $\mathrm{Fe}(\mathrm{II})$ core by hydrophobic side chains of Pro and Leu residues.
\end{abstract}

KEY WORDS Fe(II) / Peptide Complex / Polymer-Supported CysContaining Peptide / Rubredoxin Model /

X-Ray structural studies of metalloproteins showed their metal ion to be surrounded by a hydrophobic hydrocarbon layer of a certain thickness. ${ }^{1,2}$ Hydrophilic amino acid residues are located outside the proteins and enable the whole protein to dissolve in water. Hydrophobic amino acid residues, e.g., Pro and $\mathrm{Leu}$, are closest to the coordinating amino acid residues. In the case of rubredoxin, an iron-containing protein functioning as an electron transfer agent, a characteristic sequence, Cys-Pro-Leu-Cys, was found to chelate the iron ion by two cysteine thiolate groups.

The $\mathrm{Fe}(\mathrm{II})$ and $\mathrm{Fe}(\mathrm{III})$ complexes of various Cys-containing peptides were synthesized as a model of rubredoxin having one $\mathrm{Fe}(\mathrm{II}) /(\mathrm{III})$ ion surrounded by four Cys-thiolato ligands. ${ }^{3,4}$ An $\mathrm{Fe}(\mathrm{II})$ complex of Z-Cys-ProLeu-Cys-OMe ( $Z=$ benzyloxycarbonyl) was found stable in an aqueous micellar solution. ${ }^{5}$ We attempted to synthesize some watersoluble Cys-containing peptides chemically bound to poly(oxyethylene) as the hydrophilic part. Mutter et al. employed poly(oxyethylene) for peptide synthesis. ${ }^{6,7}$ Bayer et al. succeeded in the synthesis of heme-containing poly(oxyethylene) as a water-soluble model of hemoglobin. ${ }^{8} \mathrm{MoO}_{2}(\mathrm{Cys}-\mathrm{O}-\mathrm{PEG})_{2}$ was synthesized by us as a model of molybdooxidase. $^{9}$

This paper presents the synthesis of the $\mathrm{Hg}(\mathrm{II})$ and $\mathrm{Fe}(\mathrm{II})$ complexes of polymersupported Cys-containing peptides prepared by condensation at the peptide amino groups, using poly(oxyethylene) with carboxylic acid groups at both ends. The amide condensation was carried out for the following reasons. 1) The amide condensation can be performed more efficiently than the ester condensation in the presence of a considerable amount of water in commercial PEG samples. 2) The deblocking of protection groups in the side chains of peptides must be done under strongly acidic or basic conditions. For example, the removal of Acm group from Cys(Acm)-containing peptides must be carried out with 
$\mathrm{HgCl}_{2}$ and $\mathrm{H}_{2} \mathrm{~S}$ with the peptide exposed to hydrogen chloride formed by the deblocking process. 3) Most heavy metal complexes possess weak catalytic activity for the hydrolysis of ester group. ${ }^{10}$

Leibfritz et al. analyzed the structure of Boc-(Aib-L-Ala $)_{5}-\mathrm{O}-\mathrm{PEG} \quad($ Boc $=t$-butyloxycarbonyl, $\mathrm{Aib}=2$-methylalaninyl) by the ${ }^{13} \mathrm{C}$ NMR technique so as to distinguish between random coil and $\alpha$-helical conformations. ${ }^{11}$ In this paper, we detected a hydrophobic interaction between the bulky side chains of the Cys-Pro-Leu-Cys sequence in an aqueous solution of its $\mathrm{Hg}$ (II) complex. The remarkable stabilization of $\mathrm{Fe}-\mathrm{S}(\mathrm{Cys})$ bonding by such a hydrophobic effect in water was found.

\section{EXPERIMENTAL}

\section{Materials}

All solvents were purified by distillation before use. Dicyclohexylcarbodiimide (DCC) was purchased from Protein Research Institute. Potassium permanganate and poly(oxyethylene) (PEG) were obtained from Wako Chemical Co. The synthesis of $\mathrm{Z}$ Cys(Acm)-Pro-Leu-Cys(Acm)-OMe (Acm = acetamidomethyl) and $\mathrm{Hg}_{2} \mathrm{Cl}_{2}$ (Z-Cys-ProLeu-Cys-OMe $)^{12}$ was carried out by the same method in the previous paper. ${ }^{3}$

\section{Synthesis}

$\mathrm{HOOCCH}_{2}\left(\mathrm{OCH}_{2} \mathrm{CH}_{2}\right)_{n} \mathrm{OCH}_{2} \mathrm{COOH}$ $(P E G-C O O H)$. About $150 \mathrm{~g}(0.15 \mathrm{~mol})$ of PEG (MW, 2000) were dissolved in $500 \mathrm{ml}$ of water. To this solution was added an aqueous solution $(100 \mathrm{ml})$ of potassium permanganate $(25 \mathrm{~g}, 0.16 \mathrm{~mol})$ at room temperature. The mixture was stirred at $40^{\circ} \mathrm{C}$ for $4 \mathrm{~h}$. After black precipitates were filtered off, the filtrate was acidified with $2 \mathrm{~N} \mathrm{HCl}$ aq and extracted with $300 \mathrm{ml}$ of dichloromethane. The organic layer was washed twice with water. The solution was concentrated to about one-fifth the original volume under reduced pressure. The addition of $500 \mathrm{ml}$ of ether to the solution resulted in the precipitation of a white material. The content of the carboxyl group was titrated with $0.1 N \mathrm{NaOH}$ aq, using phenolphthalein as an indicator. The results indicated a conversion of about $20 \%$ of $\mathrm{OH}$ into $\mathrm{COOH}$.

$P E G-C O-C y s(A c m)-O M e(1)$. To a mixture of $\mathrm{HCl} \cdot \mathrm{Cys}(\mathrm{Acm})-\mathrm{OMe}(0.73 \mathrm{~g}, 3 \mathrm{mmol})$ and triethylamine $(0.42 \mathrm{ml}, 3 \mathrm{mmol})$ in $50 \mathrm{ml}$ of dichloromethane was added a solution of PEG-COOH (15 g; COOH content, $3 \mathrm{mmol})$ in $50 \mathrm{ml}$ of dichloromethane. $0.62 \mathrm{~g}(3 \mathrm{mmol})$ of DCC was then added with vigorous stirring at $0^{\circ} \mathrm{C}$. The mixture was allowed to stand for $48 \mathrm{~h}$ at room temperature and filtered to remove dicyclohexylurea. The filtrate was washed with water twice, dried over sodium sulfate, and concentrated to $20 \mathrm{ml}$ under reduced pressure. The addition of $200 \mathrm{ml}$ of ether resulted in the precipitation of a white solid, yield, $82 \%$. Elemental analysis for nitrogen (N, $1.37 \%$ ) indicated that about $16 \%$ of $\mathrm{Cys}(\mathrm{Acm})-\mathrm{OMe}$ had been introduced into PEG.

$P E G-C O-C y s(H g C l)-O M e$ (2). To a solution of $\mathrm{PEG}-\mathrm{CO}-\mathrm{Cys}(\mathrm{Acm})-\mathrm{OMe} \quad(4 \mathrm{~g}$, $0.3 \mathrm{mmol})$ in DMF $(2 \mathrm{ml}), 0.24 \mathrm{~g}(0.9 \mathrm{mmol})$ of $\mathrm{HgCl}_{2}$ was added at room temperature. After $100 \mathrm{ml}$ of dichloromethane were added to the solution, the mixture was washed twice with water. The organic layer was dried over sodium sulfate and filtered. A white solid was precipitated with the addition of $200 \mathrm{ml}$ of ether to the filtrate. Yield, 95\%. Two Raman bands assignable to $(\mathrm{S}-\mathrm{Hg}-\mathrm{Cl})$ were observed at 315 and $283 \mathrm{~cm}^{-1}$.

$P E G-C O-C y s-O M e$ (3). Hydrogen sulfide was passed through a solution of 2 in $50 \mathrm{ml}$ of methanol. The resulting black precipitates were filtered off and the filtrate was concentrated under reduced pressure. The white residue obtained was washed with $100 \mathrm{ml}$ of degassed ether and dried over $\mathrm{NaOH}$ under an argon atmosphere. Estimation of the $\mathrm{SH}$ group of 3 was carried out by spectroscopic titration with $2,2^{\prime}$-dithiobis(5-nitropyridine). ${ }^{13}$ 
The SH content of $\mathbf{3}$ per $1 \mathrm{~g}$ of the polymer was $0.75 \times 10^{-4} \mathrm{molg}^{-1}$. The polymer was airsensitive, soluble in water, chloroform, or $\mathrm{DMF}$, and insoluble in ether.

PEG-CO-Cys (Acm)-Pro-Leu-Cys (Acm)$O M e$ (4). Z-Cys(Acm)-Pro-Leu-Cys(Acm)$\mathrm{OMe}(0.3 \mathrm{~g}, 0.4 \mathrm{mmol})$ was dissolved in $5 \mathrm{ml}$ of $\mathrm{HBr} /$ acetic acid at room temperature. After $2 \mathrm{~h}$, the addition of $100 \mathrm{ml}$ of ether to the mixture gave $\mathrm{HBr}$ salts of the peptide, which were collected by filtration and dried over $\mathrm{NaOH}$. To a solution of the $\mathrm{HBr}$ salts $(0.2 \mathrm{~g}, 0.3 \mathrm{mmol})$ and triethylamine $(0.04 \mathrm{ml}$, $0.3 \mathrm{mmol}$ ) in $100 \mathrm{ml}$ of chloroform was added $\mathrm{PEG}-\mathrm{COOH}(3 \mathrm{~g}$; $\mathrm{COOH}, 0.3 \mathrm{mmol})$, DCC $(0.06 \mathrm{~g}, 0.3 \mathrm{mmol})$, and N-hydroxysuccinimide $(0.04 \mathrm{~g}, 0.3 \mathrm{mmol})$ at $0{ }^{\circ} \mathrm{C}$. The solution was allowed to stand at room temperature for $48 \mathrm{~h}$. The solution was filtered, washed twice with water, dried over sodium sulfate, and concentrated to $10 \mathrm{ml}$ under reduced pressure. The addition of $100 \mathrm{ml}$ of ether to the solution caused precipitation of a white solid. Yield, $85 \%$.

PEG-CO-Cys $(\mathrm{HgCl})-$ Pro-Leu-Cys$(\mathrm{HgCl})-\mathrm{OMe}$ (5). The complex was synthesized by the same procedure described for 2 . Yield, 93\%. Raman bands were found at 314 and $281 \mathrm{~cm}^{-1}$.
PEG-CO-Cys-Pro-Leu-Cys-OMe (6). The polymer was synthesized by the same method described for 3. Estimation of the $\mathrm{SH}$ group was carried out by the same method for 3 . SH content in the polymer (6) was $1.2 \times 10^{-4}$ $\mathrm{molg}^{-1}$. Yield, $80 \%$. The polymer was air sensitive, soluble in water, chloroform, or $\mathrm{DMF}$, and insoluble in ether.

Solution of $\left[\mathrm{Et}_{4} \mathrm{~N}_{2}[\mathrm{Fe}(\mathrm{PEG}-\mathrm{CO}-\mathrm{Cys}-\right.$ $\left.\mathrm{OMe})_{4}\right]$ (7) and $\left[\mathrm{Et}_{4} \mathrm{~N}\right]_{2}[\mathrm{Fe}(\mathrm{PEG}-\mathrm{CO}-\mathrm{Cys}-$ Pro-Leu-Cys-OMe $\left.)_{2}\right]$ (8). The solution was prepared from $\left[\mathrm{Et}_{4} \mathrm{~N}\right]_{2}\left[\mathrm{FeCl}_{4}\right]$ and $\mathbf{3}$ or $\mathbf{6}$ in DMF by the same method reported previously without further purification. ${ }^{5}$ An aqueous solution of 8 was prepared by the addition of water to the residue obtained at the concentration of the above DMF solution. The solution was used for the physical measurements described in this paper. The synthetic scheme is shown in Figure 1.

\section{Physical Measurements}

${ }^{13} \mathrm{C}$ NMR spectra were recorded on a JEOL FX-90Q spectrometer at $31^{\circ} \mathrm{C}$. Circular dichroism (CD) spectra were obtained on a JASCO J-40A at room temperature. The value of $\Delta \varepsilon$ was expressed in units of $\mathrm{M}^{-1} \mathrm{~cm}^{-1}$. Raman spectra were obtained so as to detect $\mathrm{Hg}-\mathrm{S}$ and $\mathrm{Hg}-\mathrm{Cl}$ bonds, using a JASCO R-

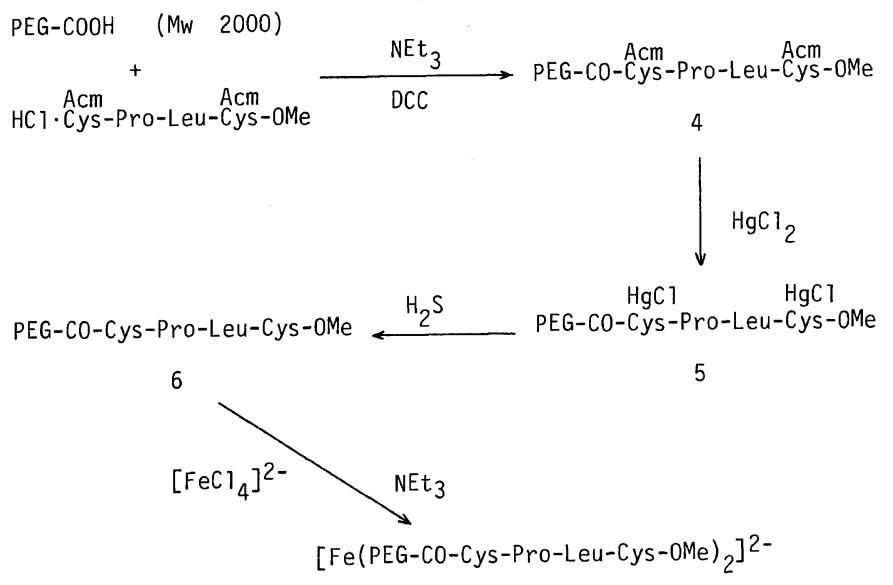

8

Figure 1. Synthetic processes of polymer-supported peptides and their $\mathrm{Hg}(\mathrm{II})$ and $\mathrm{Fe}(\mathrm{II})$ complexes. 
a)

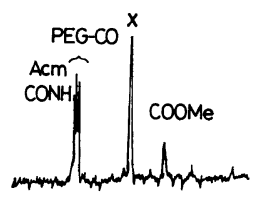

b)

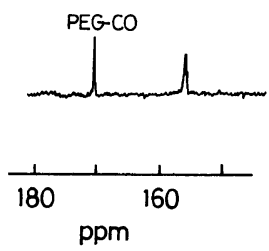

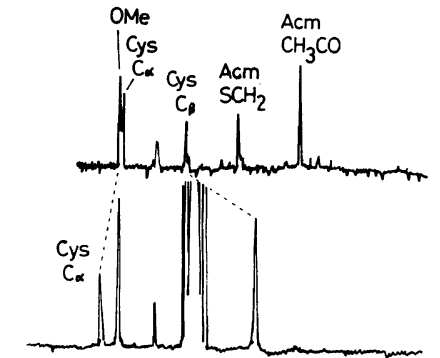

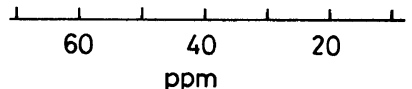

Figure 2. ${ }^{13} \mathrm{C}$ NMR spectra of a) $\mathrm{PEG}-\mathrm{CO}-\mathrm{Cys}(\mathrm{Acm})-\mathrm{OMe}$ in $\mathrm{CDCl}_{3}$ and b) $\mathrm{PEG}-\mathrm{CO}-\mathrm{Cys}(\mathrm{HgCl})-$ $\mathrm{OMe}$ in $\mathrm{Me}_{2} \mathrm{SO}-d_{6}$.

800 spectrometer at an exciting line of $488.0 \mathrm{~nm}$.

\section{RESULTS AND DISCUSSION}

\section{Structure in Solution of S-Protected Peptides}

The ${ }^{13} \mathrm{C}$ NMR spectral technique is useful for analyzing oligopeptides/metal complexes attached to PEG parts, since the methylene carbons of the PEG parts give sharp signals centered at $73 \mathrm{ppm}$ in $\mathrm{CDCl}_{3}$ or $\mathrm{Me}_{2} \mathrm{SO}-d_{6}$. Figure 2 shows the ${ }^{13} \mathrm{C}$ NMR spectra of $\mathrm{PEG}-$ $\mathrm{CO}-\mathrm{Cys}(\mathrm{Acm})-\mathrm{OMe}$ in $\mathrm{CDCl}_{3}$ and $\mathrm{PEG}-\mathrm{CO}-$ $\mathrm{Cys}(\mathrm{HgCl})-\mathrm{OMe}$ in $\mathrm{Me}_{2} \mathrm{SO}-d_{6}$. The assignments of Cys and PEG-CO parts were readily performed and shown in Figure 2. The Cys $C_{\beta}$ carbon signal of $\mathrm{Cys}(\mathrm{Acm})$ was observed at $40.1 \mathrm{ppm}$ in $\mathrm{CDCl}_{3}$, while that of $\mathrm{Cys}(\mathrm{HgCl})$ shifted to $31.0 \mathrm{ppm}$ in $\mathrm{Me}_{2} \mathrm{SO}-d_{6}$. Such a shift has also been observed for a ${ }^{13} \mathrm{C}$ NMR signal of the $\mathrm{C}_{\beta}$ carbon adjacent to a thiolato ligand coordinated to a $\mathrm{Pd}(\mathrm{II})$ ion. ${ }^{14}$ A lowfield shift (12 ppm) of $\mathrm{C}_{\beta}$ signal was induced by $\mathrm{Hg}-\mathrm{S}$ bonds (Table II) but other carbon signals, such as PEG-CO and COOMe, were not affected by such bonds. PEG-CO-Cys $(\mathrm{HgCl})-\mathrm{OMe}$ exhibited almost the same chemical shifts of ${ }^{13} \mathrm{C}$ NMR signals in $\mathrm{Me}_{2} \mathrm{SO}-d_{6}$ and in $\mathrm{D}_{2} \mathrm{O}$, as evident from the slight, steady shifts by solvation of $\mathrm{Me}_{2} \mathrm{SO}-d_{6}$ to all residues.

The ${ }^{13} \mathrm{C}$ NMR spectra of the PEG-

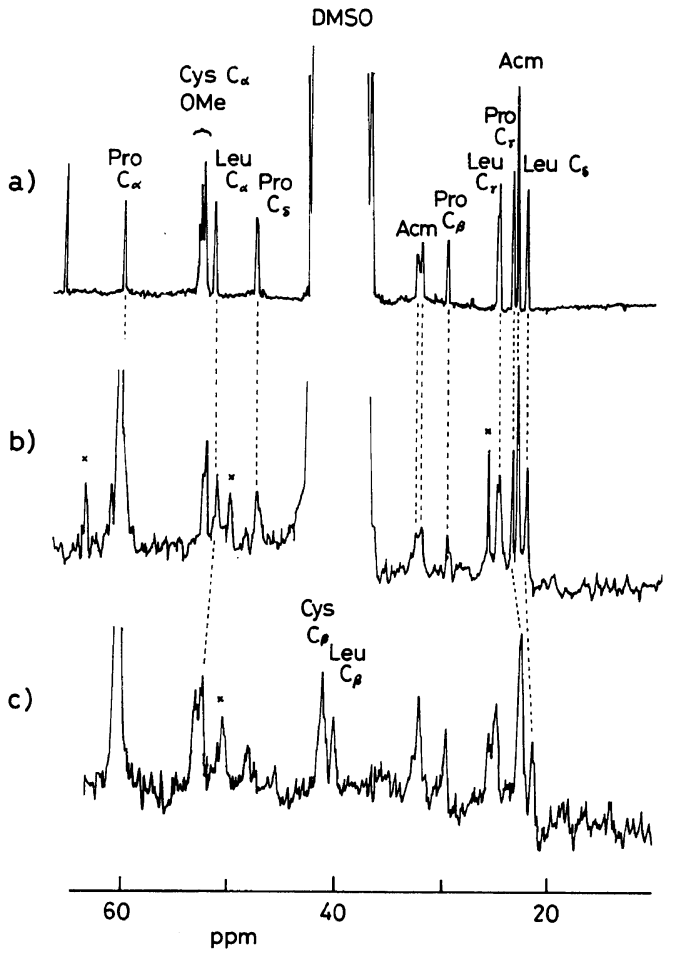

Figure 3. ${ }^{13} \mathrm{C}$ NMR spectra of a) Z-Cys(Acm)-Pro$\mathrm{Leu}-\mathrm{Cys}(\mathrm{Acm})-\mathrm{OMe}$ in $\mathrm{Me}_{2} \mathrm{SO}-d_{6}$, b) PEG-COCys(Acm)-Pro-Leu-Cys(Acm)-OMe (4) in $\mathrm{Me}_{2} \mathrm{SO}-d_{6}$ and c) 4 in $\mathrm{D}_{2} \mathrm{O}$.

supported tetrapeptide and its $\mathrm{Hg}$ (II) complex in $\mathrm{Me}_{2} \mathrm{SO}-d_{6}$ and $\mathrm{D}_{2} \mathrm{O}$ are shown in Figures 3, 4 and Tables I and II along with the spectrum of Z-Cys(Acm)-Pro-Leu-Cys(Acm)-OMe. The ${ }^{13} \mathrm{C}$ NMR signals of the polymer- 
Table I. ${ }^{13} \mathrm{C}$ NMR chemical shifts of $\mathrm{Z}-\mathrm{Cys}(\mathrm{Acm})-\mathrm{Pro}-$ Leu-Cys(Acm)-OMe and PEG-CO-Cys(Acm)-ProLeu-Cys(Acm)-OMe in $\mathrm{Me}_{2} \mathrm{SO}$ or $\mathrm{D}_{2} \mathrm{O}$

\begin{tabular}{|c|c|c|c|}
\hline \multirow[t]{2}{*}{ Compounds } & \multirow{2}{*}{$\begin{array}{c}\text { Z-Cys }(\mathrm{Acm})- \\
\text { Pro-Leu- } \\
\text { Cys }(\mathrm{Acm})- \\
\mathrm{OMe} \text { in } \\
\mathrm{Me}_{2} \mathrm{SO}-d_{6}\end{array}$} & \multicolumn{2}{|c|}{$\begin{array}{c}\text { PEG-CO-Cys(Acm)- } \\
\text { Pro-Leu-Cys(Acm)- } \\
\text { OMe } 4\end{array}$} \\
\hline & & in $\mathrm{Me}_{2} \mathrm{SO}-d_{6}$ & in $\mathrm{D}_{2} \mathrm{O}$ \\
\hline Cys $\mathrm{C}_{\alpha}$ & $\begin{array}{l}52.3 \\
52.7\end{array}$ & 52.2 & - \\
\hline $\mathrm{C}_{\beta}$ & $40.0-43.0$ & $40.0-43.0$ & 42.0 \\
\hline $\mathrm{Acm} \mathrm{S}-\mathrm{CH}_{2}$ & 31.9 & 31.9 & 31.2 \\
\hline $\mathrm{CH}_{3} \mathrm{CO}$ & 22.5 & 22.5 & 21.7 \\
\hline Pro $\mathrm{C}_{\alpha}$ & 59.5 & 59.5 & $59.5-60.5$ \\
\hline $\mathrm{C}_{\beta}$ & 29.4 & 29.4 & 29.0 \\
\hline $\mathrm{C}_{\gamma}$ & 23.1 & 23.0 & 21.7 \\
\hline $\mathrm{C}_{\delta}^{\prime}$ & 46.8 & 46.9 & 47.0 \\
\hline Leu $C_{\alpha}$ & 50.8 & 51.0 & 53.3 \\
\hline $\mathrm{C}_{\beta}$ & - & $39.0-41.0$ & 39.2 \\
\hline $\mathrm{C}_{\gamma}$ & 24.3 & 24.3 & 24.2 \\
\hline $\mathrm{C}_{\delta}$ & 21.7 & 21.7 & 20.4 \\
\hline $\mathrm{COOCH}_{3}$ & 52.0 & 52.1 & 51.8 \\
\hline $\mathrm{CH}_{2} \mathrm{Ph}$ & 65.5 & & \\
\hline
\end{tabular}

Table II. ${ }^{13} \mathrm{C}$ NMR chemical shifts of $\mathrm{Z}-\mathrm{Cys}(\mathrm{HgCl})-$ Pro-Leu-Cys $(\mathrm{HgCl})-\mathrm{OMe}$ and PEG-CO-Cys( $\mathrm{HgCl})-$ Pro-Leu-Cys( $\mathrm{HgCl})-\mathrm{OMe}$ in $\mathrm{Me}_{2} \mathrm{SO}$ or $\mathrm{D}_{2} \mathrm{O}$

\begin{tabular}{|c|c|c|c|}
\hline \multirow[t]{2}{*}{ Compounds } & \multirow{2}{*}{$\begin{array}{c}\mathrm{Z}-\mathrm{Cys}(\mathrm{HgCl})- \\
\text { Pro-Leu- } \\
\text { Cys }(\mathrm{HgCl})- \\
\mathrm{OMe} \text { in } \\
\mathrm{Me}_{2} \mathrm{SO}-d_{6}\end{array}$} & \multicolumn{2}{|c|}{$\begin{array}{c}\text { PEG-CO-Cys }(\mathrm{HgCl})- \\
\text { Pro-Leu-Cys }(\mathrm{HgCl})- \\
\text { OMe } 5\end{array}$} \\
\hline & & in $\mathrm{Me}_{2} \mathrm{SO}-d_{6}$ & in $\mathrm{D}_{2} \mathrm{O}$ \\
\hline Cys $C_{\alpha}$ & 55.1 & 55.8 & Undetected \\
\hline $\mathrm{C}_{\beta}$ & 29.8 & 29.8 & 32.0 \\
\hline Pro $\mathrm{C}_{\alpha}$ & 60.4 & 60.3 & 60.3 \\
\hline $\mathrm{C}_{\beta}$ & 29.1 & 29.1 & Undetected \\
\hline $\mathrm{C}_{\gamma}$ & 22.8 & 22.8 & 21.7 \\
\hline $\mathrm{C}_{\delta}$ & 47.1 & 47.1 & 47.0 \\
\hline Leu $C_{\alpha}$ & 51.1 & 51.1 & 50.8 \\
\hline $\mathrm{C}_{\beta}$ & $40.0-41.0$ & $40.0-41.0$ & 39.1 \\
\hline $\mathrm{C}_{\gamma}$ & 24.3 & 24.3 & 24.5 \\
\hline $\mathrm{C}_{\delta}$ & 21.4 & 21.8 & 20.7 \\
\hline $\mathrm{COOCH}_{3}$ & 51.9 & 51.9 & 52.0 \\
\hline $\mathrm{CH}_{2} \mathrm{Ph}$ & 65.5 & & \\
\hline
\end{tabular}

supported peptide were observed to have almost the same chemical shifts as those of $Z_{-}$ Cys(Acm)-Pro-Leu-Cys(Acm)-OMe. The PEG part of PEG-CO-Cys(Acm)-Pro-Leu$\mathrm{Cys}(\mathrm{Acm})-\mathrm{OMe}$ did not influence any of the a)

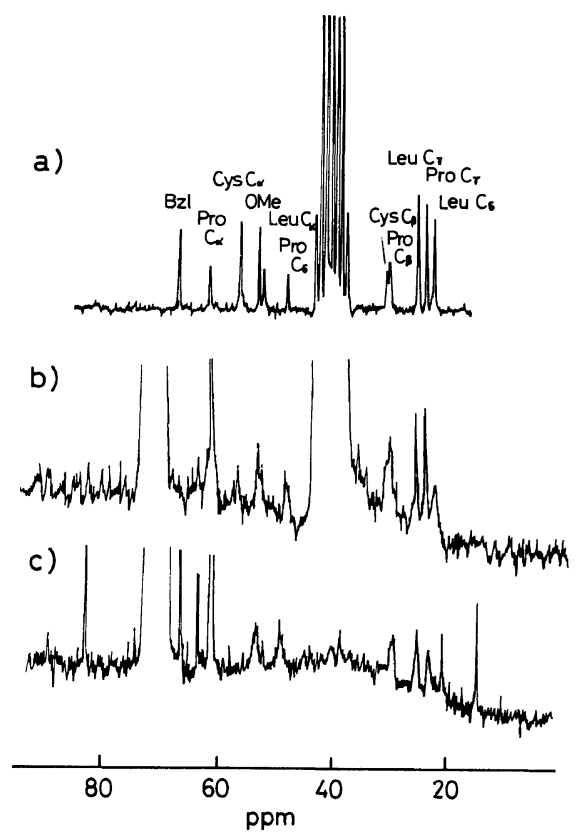

Figure 4. ${ }^{13} \mathrm{C}$ NMR spectra of a) $\mathrm{Z}-\mathrm{Cys}(\mathrm{HgCl})-\mathrm{Pro}-$ Leu-Cys $(\mathrm{HgCl})-\mathrm{OMe}$ in $\mathrm{Me}_{2} \mathrm{SO}-d_{6}$, b) PEG-CO$\mathrm{Cys}(\mathrm{HgCl})-\mathrm{Pro}-\mathrm{Leu}-\mathrm{Cys}(\mathrm{HgCl})-\mathrm{OMe}(5)$ in $\mathrm{Me}_{2} \mathrm{SO}-d_{6}$ and c) 5 in $\mathrm{D}_{2} \mathrm{O}$.

chemical shifts of the carbons listed in Table $\mathrm{I}$. The ${ }^{13} \mathrm{C}$ chemical shifts of the Leu $\mathrm{C}_{\alpha}(\Delta \delta=$ $2.3 \mathrm{ppm})(\Delta \delta$ is the difference between the chemical shifts in $\mathrm{Me}_{2} \mathrm{SO}-d_{6}$ and in $\mathrm{D}_{2} \mathrm{O}$ ), Leu $\mathrm{C}_{\delta}(\Delta \delta=1.3 \mathrm{ppm})$, and Pro $\mathrm{C}_{\gamma}(\Delta \delta=1.3 \mathrm{ppm})$ carbons in $\mathrm{D}_{2} \mathrm{O}$ suggest the occurrence of hydrophobic interactions by Pro and Leu side chains. Only a small difference in the CD spectra of methanol $\left(\Delta \varepsilon_{198}:-0.72\right)$ and water $\left(\Delta \varepsilon_{198}:-0.70\right)$ solutions was recognized. Therefore, the difference in the chemical shifts of ${ }^{13} \mathrm{C}$ NMR signals and the absence of any distinction between the $\mathrm{CD}$ spectra in $\mathrm{MeOH}$ and water are ascribed to the interactions of the side chains, but not to the change in conformational probability about amide chromophores. Thus, the slight conformational change about the chiral $\mathrm{C}_{\alpha}$ of the main chain with a hydrophobic interaction, though local interactions in the case of chains, may leads to considerable change in the chemical shifts assigned to Pro and Leu residues. 
Figure 4 and Table II show the ${ }^{13} \mathrm{C}$ NMR spectra and chemical shifts of $\mathrm{Hg}$ (II) complexes (5). The peptide part of $\mathbf{5}$ gave the same ${ }^{13} \mathrm{C}$ signals in $\mathrm{Me}_{2} \mathrm{SO}-d_{6}$ as those of $\mathrm{Hg}_{2} \mathrm{Cl}_{2}$ (Z-Cys-Pro-Leu-Cys-OMe). Assignments of the ${ }^{13} \mathrm{C}$ signals of 5 in $\mathrm{D}_{2} \mathrm{O}$ were carried out by monitoring the ${ }^{13} \mathrm{C}$ signals in mixed solvents with various ratios of $\mathrm{Me}_{2} \mathrm{SO}-d_{6} / \mathrm{D}_{2} \mathrm{O}$. Solvent-dependent shifts of the ${ }^{13} \mathrm{C}$ signals of Cys $\mathrm{C}_{\beta}(\Delta \delta=2.2 \mathrm{ppm})$, Pro $\mathrm{C}_{\gamma}(\Delta \delta=1.1 \mathrm{ppm})$, Leu $\mathrm{C}_{\alpha}(\Delta \delta=0.3 \mathrm{ppm})$, Pro $\mathrm{C}_{\delta}(\Delta \delta=1.1 \mathrm{ppm})$ were observed in $\mathrm{Me}_{2} \mathrm{SO}-d_{6}$ and $\mathrm{D}_{2} \mathrm{O}$ and are listed in Table II. The NMR results suggest the effect of a hydrophobic interaction by the side chain of the Cys-Pro-Leu-Cys sequence and $\mathbf{4}$ as well.

\section{$\mathrm{Fe}(\mathrm{II})$ Complexes of Polymer-Supported Cys- Containing Peptides}

In our previous paper, $\mathrm{Fe}(\mathrm{II})$ complexes of Cys-containing peptides, as models of rubredoxin, were characterized by visible, $C D$, and MCD spectra. ${ }^{4,5}$ Figure 5 shows the CD spectra of $\mathrm{Fe}(\mathrm{II}) / \mathrm{PEG}-\mathrm{CO}-\mathrm{Cys}-\mathrm{Pro}-\mathrm{Leu}-$ Cys-OMe $(1: 2), 8$, in DMF or $\mathrm{H}_{2} \mathrm{O}$ and $\mathrm{Fe}(\mathrm{II}) / \mathrm{PEG}-\mathrm{CO}-\mathrm{Cys}-\mathrm{OMe}(1: 4), 7$, in DMF. No $C D$ extremum was observed for the $\mathrm{Fe}(\mathrm{II}) / \mathrm{PEG}-\mathrm{CO}-\mathrm{Cys}-\mathrm{OMe}(1: 4)$ in $\mathrm{H}_{2} \mathrm{O}$ since the complex was apparently hydrolyzed completely under these conditions. 7 shows small extrema at 370 and $520 \mathrm{~nm}$ in DMF. Such a non-chelating Cys-peptide is considered not to provide a stable $\mathrm{Fe}(\mathrm{II})$ complex. ${ }^{3} \mathbf{8}$ exhibits a strong $C D$ maximum at $310 \mathrm{~nm}$ $(\Delta \varepsilon:+7.2)$ in DMF, as was also the case for a $\mathrm{Fe}(\mathrm{II})$ complex of Z-Cys-Pro-Leu-CysOMe. The strong CD extrema of $\mathbf{8}$ indicate the chelating coordination of the Cys-ProLeu-Cys sequence to a $\mathrm{Fe}(\mathrm{II})$ ion. A small shoulder at $380 \mathrm{~nm}(\Delta \varepsilon:+0.4)$ and a trough at $465 \mathrm{~nm}(\Delta \varepsilon:-0.3)$ are assignable to the CD extrema of a $\mathrm{Fe}(\mathrm{III})$ complex of PEG-COCys-Pro-Leu-Cys-OMe formed by oxidation of 8 with contaminating dioxygen.

8 in water exhibits $C D$ extremum at $318 \mathrm{~nm}$ $(\Delta \varepsilon:+1.2)$ due to ligand-metal charge transfer

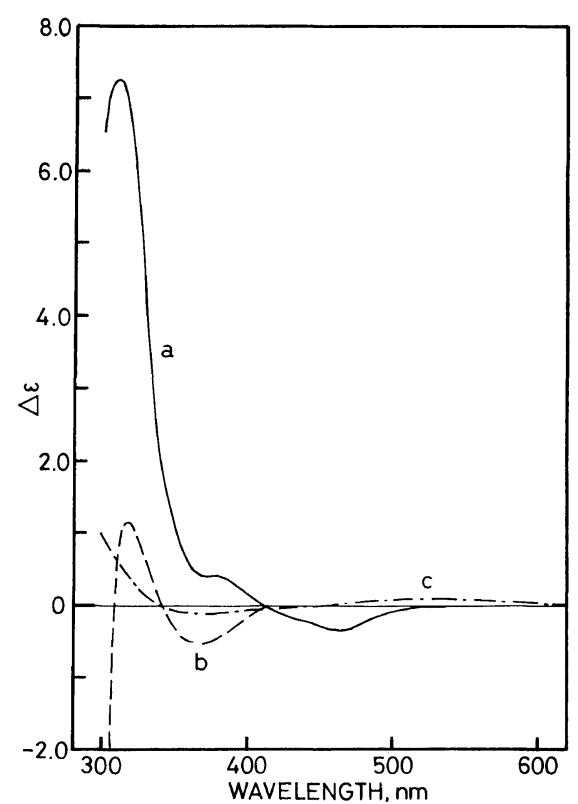

Figure 5. CD spectra of a) $\mathrm{Fe}(\mathrm{II}) / \mathrm{PEG}-\mathrm{CO}-\mathrm{Cys}-\mathrm{Pro}-$ Leu-Cys-OMe $(1: 2)(8)$ in DMF, b) 8 in $\mathrm{D}_{2} \mathrm{O}$, and c) $\mathrm{Fe}(\mathrm{II}) / \mathrm{PEG}-\mathrm{CO}-\mathrm{Cys}-\mathrm{OMe}(1: 4)$.

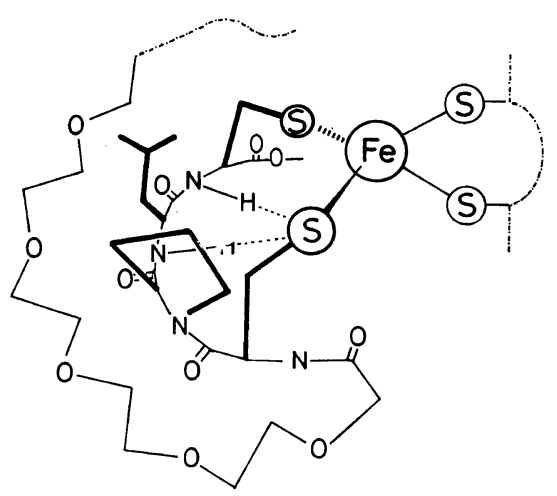

Figure 6. Proposed structure of $\mathrm{Fe}(\mathrm{II}) / \mathrm{PEG}-\mathrm{CO}-\mathrm{Cys}-$ Pro-Leu-Cys-OMe complex in aqueous solution.

of $\mathrm{S} \rightarrow \mathrm{Fe}(\mathrm{II})$ and an unusual $\mathrm{CD}$ trough at $368 \mathrm{~nm}(\Delta \varepsilon:-0.5)$. The intensity of the CD extremum at $318 \mathrm{~nm}$ indicates that $20 \%$ of 8 remains in an aqueous solution without hydrolysis. Thus, contact of $\mathbf{8}$ with large amounts of water on preparation of an aqueous solution of $\mathbf{8}$ may result in partial decomposition. However, after $\mathbf{8}$ was completely formed in an aqueous solution, the $\mathrm{Fe}(\mathrm{II})$ 
complex was stabilized by the influence of the hydrophobic side chains of Pro and Leu residues.

An Fe(II) complex of Z-Cys-Pro-Leu-CysOMe has been reported to be more resistant to hydrolysis than that of Z-Cys-Thr-Val-Cys$\mathrm{OMe}$ or Z-Cys-Ala-Ala-Cys-OMe in an aqueous micellar solution. ${ }^{5}$ The Pro and Leu side chains of the Cys-Pro-Leu-Cys sequence are thus considered to protect an $\mathrm{Fe}(\mathrm{II})$ core by a hydrophobic interaction not only in an aqueous micellar solution, but in an aqueous solution of the PEG-supported peptide complex, as shown in Figure 6. The entire molecule of $\mathbf{8}$ is solubilized in an aqueous solution by the PEG part. From the present results, stability of Fe-thiolato bonding in native rubredoxin against hydrolysis is thus demonstrated.

\section{REFERENCES}

1. K. D. Watenpaugh, L. C. Sieker, and L. H. Jensen, $J$. Mol. Biol., 131, 509 (1979).
2. T. Tsukihara, K. Fukuyama, H. Tahara, Y. Katsube, Y. Matuura, N. Tanaka, M. Kakudo, K. Wada, and H. Matsubara, J. Biochem., 84, 1645 (1978).

3. M. Nakata, N. Ueyama, T. Terakawa, and A. Nakamura, Bull. Chem. Soc. Jpn., 56, 3647 (1983).

4. N. Ueyama, M. Nakata, M. Fuji, and A. Nakamura, Inorg. Chem., in press.

5. M. Nakata, N. Ueyama, M. Fuji, A. Nakamura, K. Wada, and H. Matsubara, Biochim. Biophys. Acta, 788, 306 (1984).

6. E. Bayer and M. Mutter, Chem. Ber., 107, 1344 (1974).

7. M. Mutter, R. Uhmann, and E. Bayer, Ann. Chem., 905 (1975).

8. E. Bayer and G. Holbach, Angew. Chem. Int. Ed. Engl., 16, 117 (1977).

9. N. Ueyama, E. Kamada, and A. Nakamura, Polym., J., 15, 519 (1983).

10. (a) H. Kroll, J. Am. Chem. Soc., 74, 2036 (1952). (b) J. P. Collman and D. A. Buckingham, J. Am. Chem. Soc., 85, 3039 (1963).

11. D. Leibfritz, W. Mayer, R. Oekonomopulos, and G. Jung, Tetrahedron, 34, 2045 (1978).

12. Small letter cys refers to a residue coordinating to a metal ion.

13. A. Swatditat and C. C. Tsen, Anal. Chem., 45, 349 (1972).

14. N. Ueyama, K. Sasaki, M. Nakata, and A. Nakamura, Bull. Chem. Soc. Jpn., 55, 2364 (1982). 